\title{
IMPROVING THE GLOBAL SUSTAINABILITY OF THE AREZZO TOTAL RECOVERY WASTE TREATMENT PLANT
}

\author{
Francesco Di Maria ${ }^{1,2, *}$, Federico Sisani ${ }^{1}$ and Marzio Lasagni ${ }^{3}$ \\ ${ }^{1}$ LAR5 Laboratory, Engineering Departiment University of Perugia, via G. Duranti 93, 06125, Perugia, Italy \\ ${ }^{2}$ CIMIS Consortium, via G. Duranti 67, 06125, Perugia, Italy \\ ${ }^{3}$ AISA Impianti SpA, Strada Vicinale dei Mori, loc. San Zeno, 52100, Arezzo, Italy
}

Article Info:

Received:

30 November 2018

Revised:

11 January 2019

Accepted:

28 January 2019

Available online:

31 March 2019

Keywords:

Anaerobic digestion

Bio-waste

Bio-methane

Composting

Cumulative energy demand

Incineration

\section{ABSTRACT}

The effectiveness of an existing integrated waste treatment plant aimed at the total recovery of waste to replace primary energy was investigated. The cumulative energy demand (CED) (MJ) was quantified using a life cycle approach. Mass and energy balances were determined for all the main inlet and outlet energetic and mass flows from the integrated plant. The current scenario was compared with a modified one where the amount of bio-waste processed was increased by using a new anaerobic digestion section for bio-methane production. The main results showed that there was a higher positive CED for the chemicals needed for operating the flue gas cleaning system. In particular urea gave the highest CED. In both the base and modified case the CED replaced by the recovered energy and fuels was higher than all the CED associated with the inlet flows, leading to a negative value of the net CED.

\section{INTRODUCTION}

According to the $\operatorname{COM}(2015) 614$ final $(E C, 2015)$ entitled "Closing the Loop - An EU action plan for the Circular Economy", waste management plays a very central role in implementing the circular economy by the effectiveness in executing the waste management hierarchy. This indicates the goals to be pursued in a hierarchic order in waste management with the aim of replacing raw materials and fuels by using waste materials. As known these goals are: prevention; reuse; recycling; recovery including energy recovery; disposal. The core of the hierarchy consists in using as much as possible the material inside the waste, able to replace or avoid the consumption of other raw materials.

The concept of the best use of resources aimed at preserving the global resources of the world is also a main concept at the basis of sustainable development.

From this point of view waste treatment and recovery/ recycling facilities are coherent with the implementation of circular economy and sustainable development if they are able to replace other raw materials and fuels.

According to this perspective, particular attention has to be focused on waste-to-energy (WtE) plants since their operation also requires the consumption of other materials necessary for both gas cleaning and maintenance of engine/plant components. Regarding this aspect, the COM (2017) 34 final (EC, 2017) indicates anaerobic digestion
(AD) with effective use on land of the digestate as a recycling operation and incineration performed at high energy efficiency as a recovery operation. This latter is coded as a recovery operation $\mathrm{R} 1-$ Use of waste as fuel or other means to generate energy (Annex II of WFD, 2008). For this aim, with the latest waste framework directive (WFD, 2008), the EC introduced the energy efficiency formula, Equation 1, to be used for assessing the efficiency of WtE. If the energy efficiency results $\geq 0.6$ for plants operating within the $1^{\text {st }}$ January 2009 or $\geq 0.65$ for those permitted after the $31^{\text {st }}$ December 2008, then these plants are operating at high energy efficiency and hence are considered as a recovery (R1), instead of a disposal (D10) operation.

Energy Efficiency $=K c \cdot \frac{E p-(E f+E i)}{0.97 \cdot(E w+E f)}$

$\mathrm{K}_{\mathrm{c}}=$ climatic factor;

$\mathrm{E}_{\mathrm{p}}=$ energy produced (electrical+thermal);

$\mathrm{E}_{\mathrm{f}}=$ energy consumed by the plant different from waste but able to generate steam;

$E_{i}=$ other energy consumed different from $E_{w}$ and $E_{f}, E_{w}=e n-$ ergy from waste.

Equation 1 accounts only for direct energetic flows and not for other relevant flows of materials and hence indirect energy consumption necessary for operating the plant.

The aim of the present study was to address the ability
* Corresponding author

Francesco Di Maria

email: francesco.dimaria@unipg.it
Detritus / Volume 05 - 2019 / pages 29-35

https://doi.org/10.31025/2611-4135/2019.13779

(c) 2018 Cisa Publisher. Open access article under CC BY-NC-ND license 
of two different scenarios related to an existing integrated waste treatment plant operating in the city of Arezzo (Italy) (Di Maria et al., 2018a) to replace primary energy. The first scenario, base scenario, is the current configuration. In the modified scenario the amount of waste treated was increased and a new anaerobic section with biogas upgrading was also implemented. Incidentally, considering the main outputs of the integrated waste treatment plant, the more it is able to replace primary energy, the more efficient it will be in implementing sustainable concepts.

For assessing the primary energy consumed and replaced, a life cycle perspective approach was used by the cumulative energy demand (CED) (MJ) single issue indicator (Frischknecht et al., 2015; Gurzenich et al., 1999; Huijbregts et al., 2006,2010).

\section{MATERIALS AND METHODS}

\subsection{The base scenario}

The integrated waste treatment and recovery plant is located in Arezzo, central Italy, and currently consists of three main sections: an incinerator with energy recovery operating at high efficiency (R1); a composting facility for recycling the bio-waste from separated collection for producing organic fertilizer; a mechanical biological treatment plant (MBT) consisting of two main sections: mechanical sorting; bio-stabilization. The total amount of waste currently processable is about $100,000 \mathrm{Mg}$ /year. Figure 1 reports the main amount of waste treated in the different sections of the plant from 2010 to 2014.

The whole energetic demand of the area is supplied by incineration (Figure 2). This facility processes about

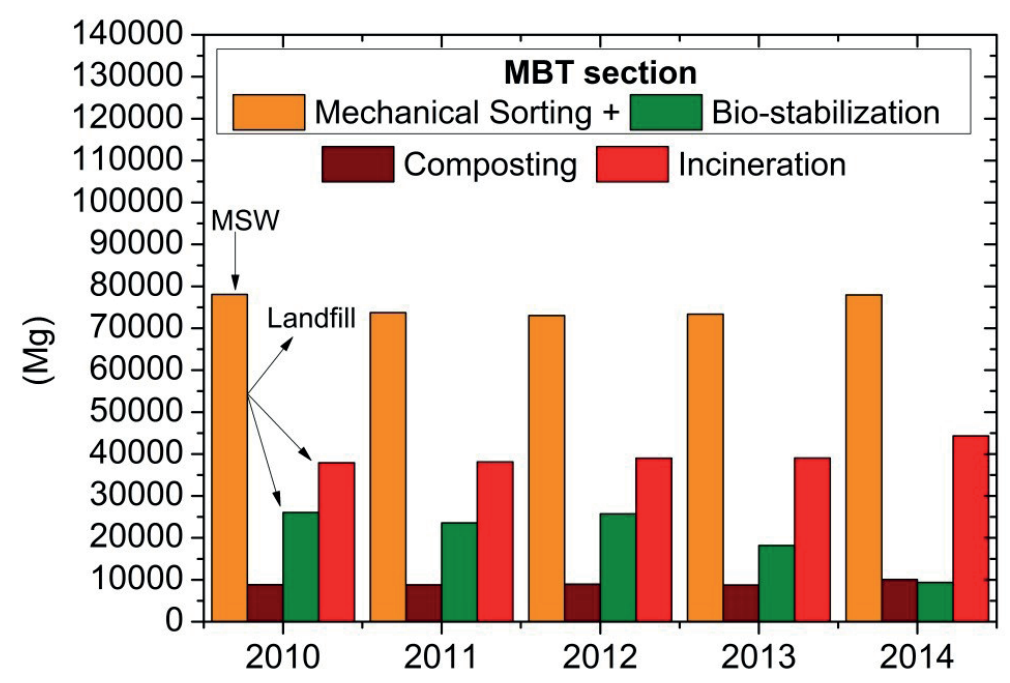

FIGURE 1: Amount of waste entering the different sections of the integrated treatment and recovery plant (first section entered by waste: MSW, mechanical sorting; bio-waste, composting).

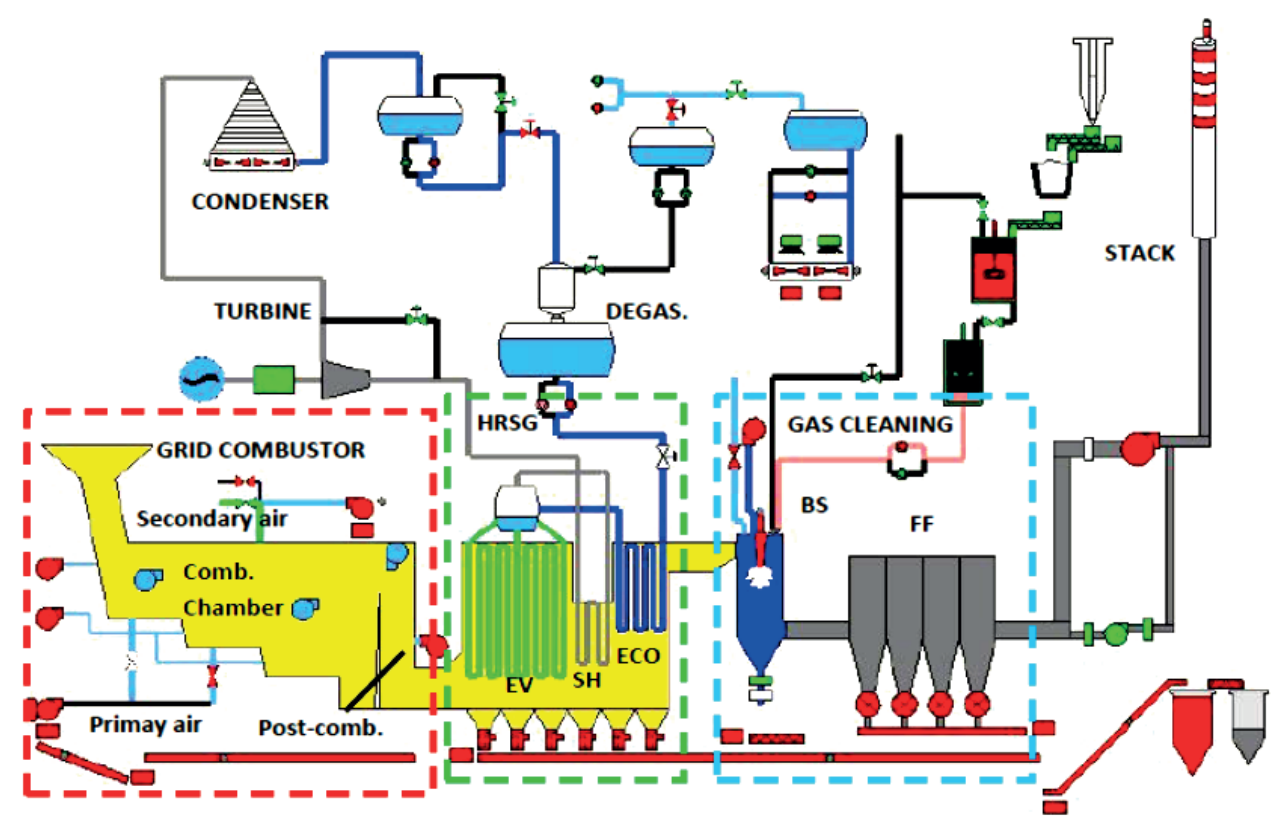

FIGURE 2: Diagram of the waste-to-energy (WtE) plant and the main components. (HRSG=heat recovery steam generator - EV=evaporator - $\mathrm{SH}=$ super heater $-\mathrm{ECO}=$ economizer $-\mathrm{BS}=$ basic reactor $-\mathrm{FF}=$ fabric filters $)$. 
40,000 Mg/year of non-hazardous municipal solid waste (MSW), recovering about $18,000 \mathrm{MWh} /$ year of gross electrical energy (Di Maria et al., 2018a).

The net electrical energy delivered to the grid is about $10,500 \mathrm{MWh}$ /year. On average about 9,000 Mg/year of slags (i.e. about $20 \%$ of the inlet MSW) are generated and disposed of in landfill. Values for energy, fuel and material consumption for the disposal of each $\mathrm{Mg}$ of waste in landfill were retrieved from the study of Doka (2009) (Table 1). Treatment of the leachate generated from the landfill was assumed to be completely processed in an off-site wastewater treatment plant (WWTP) (Di Maria et al., 2018b; Renoun et al., 2008). Considering the very low level of organic residues, i.e. total organic carbon (TOC) $<2 \%$, in the slags, the amount of landfill gas generated was assumed null.

The flue gas treatment system consists of two main components: a semi-dry reactor for removing acid pollutants using calcium hydroxide; a fabric filter rack for particulate removal. Activated carbon is also injected between the basic reactor and the fabric filter section. NOx is removed by non-catalytic selective reduction using urea $\mathrm{CO}\left(\mathrm{NH}_{2}\right)_{2}$ as the source of ammonia injected directly into the post-combustor. All the data concerning the plant performance including the consumption of chemicals and auxiliary fuel were duly recorded by the plant manager and used for the present analysis.

The bio-waste recycling section is based on aerobic treatment for the production of an organic fertilizer able to process up to $23,000 \mathrm{Mg} /$ year of bio-waste from separated collection (Figure 3 ).

All the operations are performed inside a building from which the exhaust air is moved to biofilters by electric fans. The bio-waste is put in heaps of about $300 \mathrm{Mg}$, on aerated floors. Process air is supplied by fans. The whole electrical consumption of this section is about $1,100 \mathrm{MWh} /$ year. The fraction of organic fertilizer recovered is on average $25 \%$ of the bio-waste processed (Table 2).

The MBT facility processes all the MSW entering the integrated waste treatment and recovery plant. About $40,000 \mathrm{Mg} /$ year of the material from the mechanical sorting section of the MBT are incinerated, whereas the rest
TABLE 1: Mass and energy flows related to the disposal of $1 \mathrm{Mg}$ of waste in landfill.

\begin{tabular}{l|c:c}
\hline Parameter & Value & Reference \\
\hline Leachate to WWTP & $0.025 \mathrm{Mg} / \mathrm{Mg}$ & Doka (2009) \\
\hline Fuel (diesel) & $46.7 \mathrm{MJ} / \mathrm{Mg}$ & \\
\hline HDPE liners & $0.285 \mathrm{~kg} / \mathrm{Mg}$ & \\
\hdashline Gravel & $160.4 \mathrm{~kg} / \mathrm{Mg}$ & \\
\hdashline Energy recovery & $43 \mathrm{kWh} / \mathrm{Mg}$ & Di Maria et al. (2013) \\
\hline
\end{tabular}

TABLE 2: Amount of fertilizer and total organic carbon (TOC) content in the fertilizer from bio-waste.

\begin{tabular}{l|c:c} 
Parameter & Amount & Unit \\
\hline $\mathrm{N}$ & $17.2 \pm 0.48$ & $\mathrm{~kg} / \mathrm{Mg}$ compost \\
\hdashline $\mathrm{P}_{2} \mathrm{O}_{5}$ & $8.33 \pm 0.42$ & $\mathrm{~kg} / \mathrm{Mg}$ compost \\
\hdashline $\mathrm{K}_{2} \mathrm{O}$ & $10.9 \pm 0.90$ & $\mathrm{~kg} / \mathrm{Mg}$ compost \\
\hdashline $\mathrm{TOC}$ & $254 \pm 6.20$ & $\mathrm{~kg} / \mathrm{Mg}$ compost \\
\hline
\end{tabular}

Legend: * = average content on the basis of $n=38$ chemical analyses, $k=2$ confidential level $95 \%$ and respective standard deviation.

is moved to landfill together with the undersize from the bio-stabilization section. A given fraction of the dry stream is moved to the incinerator and the remaining is landfilled. About $43 \mathrm{kWh} / \mathrm{Mg}$ of electrical energy was assumed to be recovered from the landfill gas generated by the disposal of both waste after MBT and residues from composting (Table 1).

\subsection{Modified scenario}

In the modified scenario the whole amount of bio-waste processed was increased to $58,000 \mathrm{Mg} /$ year. $35,000 \mathrm{Mg}$ / year was pre-treated in a new $A D$ section. The biogas was upgraded for the production of biomethane to be injected in the local grid for replacing natural gas.

The $A D$ section is based on a solid anaerobic digestion batch process (SADB) (Di Maria et al., 2012a,b) and generates on average about $120 \mathrm{Nm}^{3}$ of biogas for each $\mathrm{Mg}$ of bio-waste. The methane concentration is expected to be about $60 \%$ and the amount of biomethane generable about $70 \mathrm{Nm}^{3} / \mathrm{Mg}$.

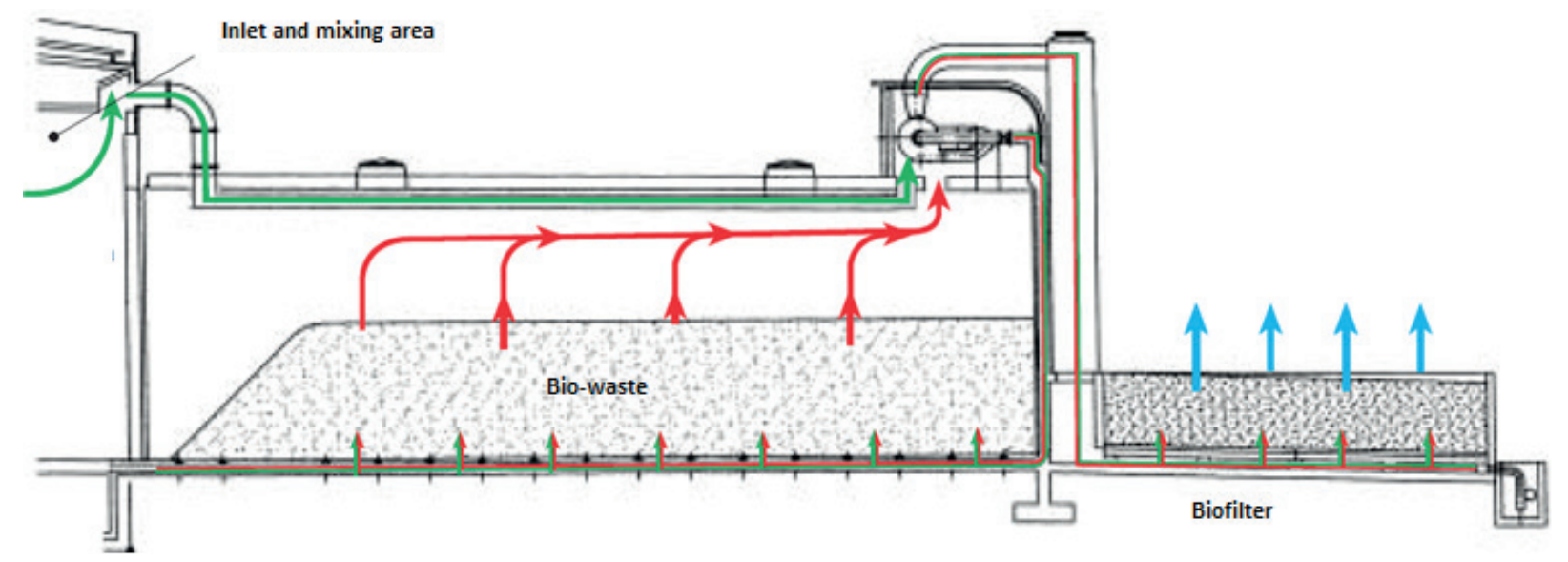

FIGURE 3: Scheme of the composting facility. (green: ambient air; red: exhaust air; blue: filtered exhaust air). 
The upgraded system is based on semipermeable membranes (Micale, 2015) with an average electrical energy consumption of about $3.5 \mathrm{kWh} / \mathrm{Nm}^{3}$ of bio-methane. After AD, the digestate was post-composted. The amount of final organic fertilizer produced was about $12,000 \mathrm{Mg}$ / year. The increase in energy consumption of the composting section was assumed to be proportional to the amount of bio-waste processed. The same data for landfilling of residues and slags (Table 1 ) and the same amount of nutrients and TOC as the base scenario for the organic fertilizer recovered were also assumed (Table 2 ).

\subsection{Primary energy demand}

The aim of using CED was to investigate the exploitation of primary energy through the life cycle of a good or a service (Frischknecht et al., 2015; Huijbregts et al., 2006, 2010), including the extraction of raw materials, the industrial production process, and their use and disposal, also taking into account the energy, fuel and materials consumed or required for all these operations. Basically incinerators require chemicals for the gas cleaning system and auxiliary fuel, but they are also able to replace energy, electricity and/or heat. Both these aspects have been included in the global energetic analysis using CED (Huijbregts et al., 2006). The consumption of other chemicals and materials such as those necessary for the boiler and for the steam turbine were not accounted for due to their limited amounts. Likewise, capital expenditures for building the incinerator and successive disposal were neglected.

Primary energy considered by CED was grouped as non-renewable and renewable (Table 3), depending on the specific industrial process considered. Industrial processes were retrieved from the Ecoinvent 3.0 database referring to the average EU industrial production system (Wernet et al., 2016).

The average EU market of electrical and heat energy was considered as the primary energy replaced by the energetic recovery from incineration (Wernet et al., 2016). Likewise the same was considered for the energy recovered from the landfill gas generated by the waste disposed in landfill after MBT and for residues from composting (Table 1). The substitution ratio of natural gas and bio-methane was assumed to be 1:1.

The values of the materials, chemicals, fuels consumed and the energy recovered by the incinerator from 2010 to 2014 (Table 4) were used for calculating the specific CED values (Table 5).

\section{RESULTS AND DISCUSSION}

The main results showed that the largest consumption of primary energy for the base scenario was associated with the chemicals needed for the flue gas treating system. Urea was the chemical that gave the highest absolute CED ranging from about $11,500 \mathrm{GJ} /$ year for 2011 to about $28,000 \mathrm{GJ} /$ year for 2010 . Primary energy associated with the other chemicals and the diesel fuel were practically similar even if there was a particularly high value for diesel fuel in 2014.

The avoided primary energy due to energy recovery was on average about $100,000 \mathrm{GJ} /$ year, which was quite constant throughout the years except for 2010.

Figure 4 reports the CED (MJ) of the different mass and energy flows for each year considered, highlighting the amount of primary energy replaced due to the net electrical energy delivered to third parties, which was always higher than the amount of primary energy consumed by the plant.

TABLE 3: Primary energy accounting for the cumulative energy demand (CED) calculation.

\begin{tabular}{|c|c|c|}
\hline Energy group & Subcategory & Primary energy included \\
\hline \multirow{3}{*}{ Non-renewable } & Fossil & $\begin{array}{l}\text { Hard coal, lignite, crude oil, natural } \\
\text { gas, coal mining off-gas, peat }\end{array}$ \\
\hline & Nuclear & Uranium \\
\hline & Primary forest & $\begin{array}{l}\text { Wood and biomass from primary } \\
\text { forests }\end{array}$ \\
\hline \multirow{5}{*}{ Renewable } & Biomass & $\begin{array}{l}\text { Wood, food products, biomass } \\
\text { from agriculture }\end{array}$ \\
\hline & Wind & Wind energy \\
\hline & Solar & Solar energy (heat and electricity) \\
\hline & Geothermal & Geothermal energy $(100-300 \mathrm{~m})$ \\
\hline & Water & $\begin{array}{l}\text { Run-of-river hydro power, reservoir } \\
\text { hydro power }\end{array}$ \\
\hline
\end{tabular}

TABLE 4: Main materials and energy flows for the integrated waste treatment plant from 2010 to 2014.

\begin{tabular}{|c|c|c|c|c|c|}
\hline \multirow[b]{2}{*}{ Parameter } & \multicolumn{5}{|c|}{ Year } \\
\hline & 2010 & 2011 & 2012 & 2013 & 2014 \\
\hline \multicolumn{6}{|l|}{ Chemicals (kg) } \\
\hline Act. Carbon & 18,740 & 18,860 & 141,20 & 16,060 & 24,080 \\
\hline Urea & 439,100 & 180,660 & 220,840 & 219,860 & 378,050 \\
\hline $\mathrm{Ca}(\mathrm{OH})_{2}$ & 554,100 & 496,800 & 629,430 & 598,970 & 647,940 \\
\hline \multicolumn{6}{|l|}{ Energy (kWhe) } \\
\hline Net Electricity & $10,058,064$ & $10,718,634$ & $10,752,468$ & $10,528,875$ & $10,690,287$ \\
\hline \multicolumn{6}{|l|}{ Fuel (kg) } \\
\hline Diesel & 33,239 & 15,070 & 30,955 & 28,714 & 98,612 \\
\hline \multicolumn{6}{|l|}{ MSW (tonnes) } \\
\hline Burned & 37,929 & 38,123 & 39,029 & 39,073 & 44,358 \\
\hline
\end{tabular}


TABLE 5: Cumulative energy demand (CED) for chemicals, fertilizer, fuel and energy production on the average market in the EU (Wernet et al., 2016).

\begin{tabular}{|c|c|c|c|c|c|c|c|}
\hline & \multicolumn{7}{|c|}{ Primary energy (MJ) } \\
\hline & Fossil & Nuclear & Primary forest & Biomass & Renew.* & Water & Total \\
\hline \multicolumn{8}{|l|}{ Chemicals (1kg) } \\
\hline Activated Carbon & 102.8 & 8.26 & 0.00 & 1.91 & 0.52 & 1.32 & 114.8 \\
\hline $\mathrm{Ca}(\mathrm{OH})_{2}$ & 3.580 & 0.34 & 0.00 & 0.01 & 0.00 & 0.24 & 4.170 \\
\hline $\mathrm{CO}\left(\mathrm{NH}_{2}\right)_{2}$ & 59.30 & 2.87 & 0.00 & 0.59 & 0.16 & 0.70 & 63.63 \\
\hline \multicolumn{8}{|l|}{ Fertilizer (1kg) } \\
\hline $\mathrm{N}$ as Urea & 57.36 & 1.72 & 0.00 & 0.73 & 0.09 & 0.67 & 60.57 \\
\hline $\mathrm{P}$ as $\mathrm{P}_{2} \mathrm{O}_{5}$ & 28.86 & 1.47 & 0.01 & 0.56 & 0.09 & 0.54 & 31.54 \\
\hline $\mathrm{K}$ as $\mathrm{K}_{2} \mathrm{O}$ & 7.080 & 0.34 & 0.00 & 0.21 & 0.02 & 0.14 & 7.790 \\
\hline \multicolumn{8}{|l|}{ Fuel } \\
\hline Diesel (1kg) & 55.78 & 0.40 & 0.00 & 0.07 & 0.02 & 0.10 & 56.37 \\
\hline Nat. gas $\left(1 \mathrm{Nm}^{3}\right)$ & 46.51 & 0.67 & 0.00 & 0.04 & 0.02 & 0.22 & 47.46 \\
\hline \multicolumn{8}{|l|}{ Energy $(1 \mathrm{kWh})$} \\
\hline Electricity & 5.42 & 3.80 & 0.00 & 0.44 & 0.21 & 0.68 & 10.56 \\
\hline Heat & 4.10 & 0.08 & 0.00 & 0.01 & 0.01 & 0.02 & 4.210 \\
\hline \multicolumn{8}{|c|}{ Slags disposal (1Mg) } \\
\hline Landfill & 2.191 & 0.081 & $6 \mathrm{E}-5$ & 0.028 & 0.007 & 0.061 & 2.368 \\
\hline
\end{tabular}

Legend: * = other renewable primary energy (Table 3).

In particular the CED necessary for waste landfilling was practically equal to the CED replaced by the energy recovery of the landfill gas.

These results indicate that for the case of incineration the amount of chemicals consumed was mainly a consequence of the MSW composition rather than its quantity. The net electrical energy delivered to third parties can also be influenced by particular maintenance operations occurring in specific years (e.g. 2010). Incidentally, these results also indicate that, in general, the plant is managed at a quite constant thermal power level. In fact, in general, the higher was the LHV waste, the lower was the Mg of waste burned, but the amount of electricity recovered remained quite constant.

In the modified scenario there was an increase in the amount of bio-waste processed. On one hand this caused a reduction in the amount of electrical energy delivered to third parties, but on the other hand an increase in the replaced CED by the substitution of natural gas with bio-methane (Figure 5). The higher electrical consumption

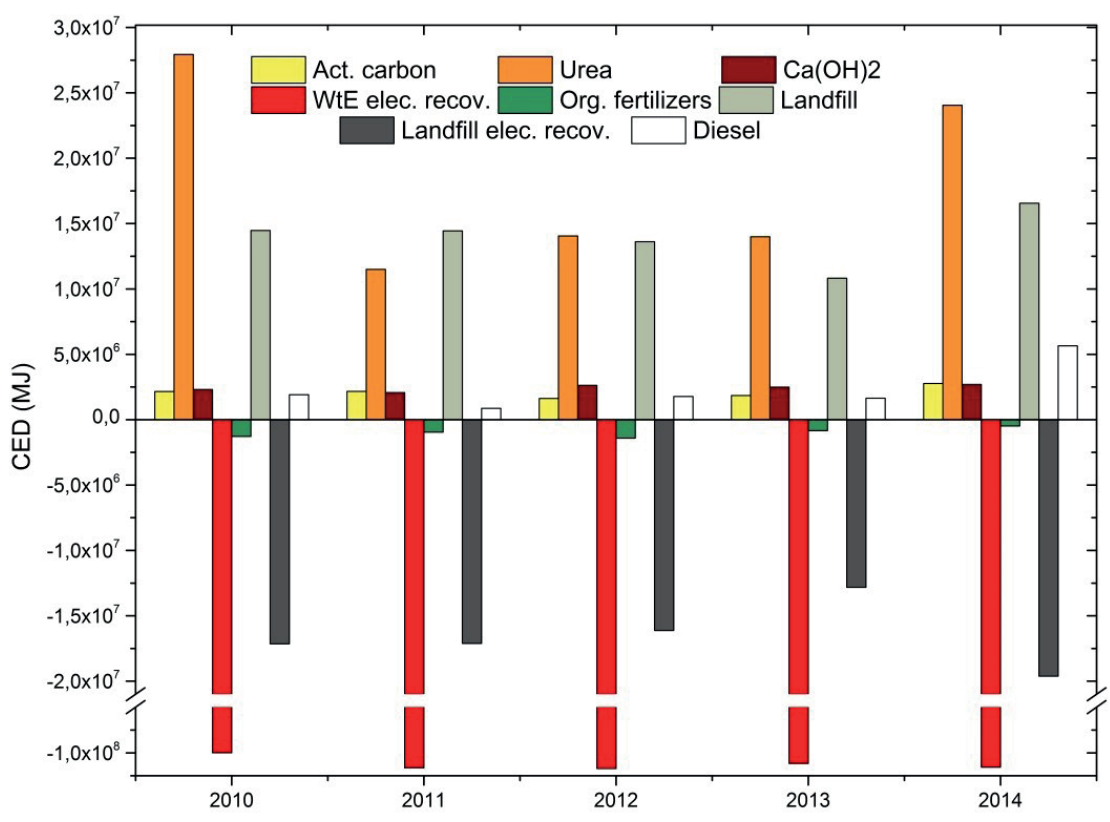

FIGURE 4: Cumulative energy demand (CED) of different energetic and materials flows for the base scenario. 


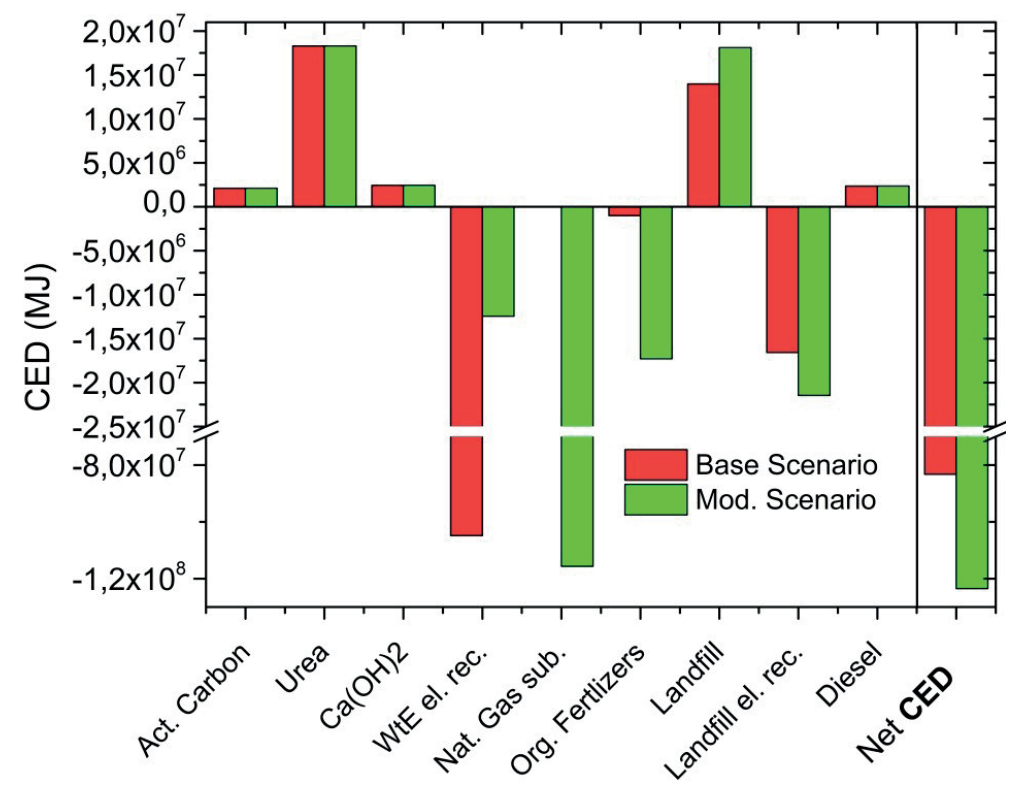

FIGURE 5: Cumulative energy demand (CED) of different energetic and materials flows for the base and modified scenarios.

was due to the larger amount of bio-waste to be treated in the $A D$ section and by the energy needs of biogas upgrading. Globally the CED replaced was higher for the modified scenario compared to the base one. The positive effects of incineration compared to other disposal operations such as landfill have already been reported in the literature. The benefits of incineration compared to landfill concerning the reduction of global warming, acidification and eutrophication were reported by Assamoi and Lawrysyn (2012). The positive effects of incineration in the management of residual waste and for the production of energy compared to fossil fuels were also reported by Buttol et al. (2007) and Rigamonti et al. (2009), respectively. Antonopoulos et al. (2013) identified incineration together with AD as the solution able to lead to maximum benefits for waste management in the Peloponnese region of Greece.

\section{CONCLUSIONS}

Management of particular waste streams such as those arising from nondifferentiated collection and from recycling operations and bio-waste requires adequate facilities and technologies for their proper treatment.

A response to such approach can be given with a high level of effectiveness and efficiency by integrated plants in which different treatments can be performed, also according to the concept of industrial symbiosis. Rejects in terms of materials and energy from one process can be exploited by another process for further recycling and recovery operations.

Of course the economic aspect requires the implementation of facilities able to treat an adequate amount of waste that generally, with the exception of large cities, cannot be delivered by single municipalities. For this reason integrated waste treatment and recovery plants have to be conceived for serving an adequate number of municipalities in a given geographical area.
Energetic recovery both in terms of electricity and heat and in terms of bio-fuels, such as bio-methane from residual waste and bio-waste was able to achieve an effective replacement of other primary energies including fossil fuels. The positive results concerning the energy aspects need to be improved by extending such analysis also to environmental, social and economic consequences also in comparison with the latest recycling goals imposed by the new EU directives of the sector. From this point of view it is necessary to better position waste recycling with the waste-to-energy process for highlighting the limits of the sustainability of these two approaches.

Furthermore, the proposed approach based on the cumulative energy demand was useful for a better positioning of waste-to-energy within the waste hierarchy.

\section{REFERENCES}

Antonopoulos, L.S., Karagiannidis, A., Tsatsarelis, T., et al. 2013. Applying waste management scenarios in the Peloponnese region in Greece: A critical analysis in the frame of life cycle assessment. Environmental Science and Pollution Research 20,2499-2511.

Assamoi, B., Lawryshyn, Y. 2012. The environmental comparison of landfilling vs. incineration of MSW accounting for waste diversion. Waste Management 32,1019-1030.

Buttol, P., Masoni, P., Bonoli, A., et al. 2007, LCA of integrated MSW management systems: Case study of the Bologna District. Waste Management 27,1059-1070.

Di Maria, F., Sordi, A., Micale, C.2012a. Energy production from mechanical biological treatment and composting plants exploiting solid anaerobic digestion batch: An Italian case study. Energ Conv Manage 56,112-120.

Di Maria, F., Sordi, A., Micale, C. 2012b. Optimization of Solid State Anaerobic Digestion by Inoculum Recirculation: The Case of an Existing Mechanical Biological Treatment Plant. App Energ; 97,462-469.

Di Maria, F., Sordi, A., Micale, C. 2013. Experimental and life cycle assessment analysis of gas emission from mechanically-biologically pretreated waste in a landfill with energy recovery. Waste Manage 33,2557-2567.

Di Maria, F., Bidini, G., Lasagni, M., Boncompagni, A. 2018a. On time measurement of the efficiency of a waste-to-energy plant and evaluation of the associated uncertainty. App Ther Eng 129,338-344. 
Di Maria, F., Sisani, F., Contini, S., Ghosh, S.K. 2018b. Impact of different schemes for treating landfill leachate. Waste Management 71,255266.

Doka, G. 2009. Life Cycle Inventories of Waste Treatment Services. Ecoinvent report No. 13. Swiss Centre for Life Cycle Inventories, Dubendorf, 2009

EC. 2015. COM(2015) 614 Final. COMMUNICATION FROM THE COMMISSION TO THE EUROPEAN PARLIAMENT, THE COUNCIL, THE EUROPEAN ECONOMIC AND SOCIAL COMMITTEE AND THE COMMITTEE OF THE REGIONS Closing the loop - An EU action plan for the Circular Economy. Brussels, 2.12.215. Available at: < https://eur-lex.europa.eu/resource.html?uri=cellar:8a8ef5e8-99a0-11e5-b3b7-01aa75ed71a1.0012.02/D0C_1\&format=PDF> (accessed on 12.06.2018).

EC, 2017. COM(2017) 34 final. COMMUNICATION FROM THE COMMISSION TO THE EUROPEAN PARLIAMENT, THE COUNCIL, THE EUROPEAN ECONOMIC AND SOCIAL COMMITTEE AND THE COMMITTEE OF THE REGIONS The role of waste-to-energy in the circular economy. Brussels 26.1.2017. Available at: < http://ec.europa.eu/environment/waste/waste-to-energy.pdf>. (accessed 12.06.2018).

Frischknecht, R., Wyss, F., Knöpfel, S.B., Lützkendorf, T., Balouktsi, M. 2015. Cumulative energy demand in LCA: the energy harvested approach. Int J Life Cycle Assess 20,957-969.

Gurzenich, D., Mathur, J., Bansal, N.K., Wagner, H.J. 1999. Cumulative energy demand for selected renewable energy technologies. Int J Life Cycle Assess.4,143-149.
Huijbregts, M.A.J., Rombouts, L.J.A., Hellweg, S., Frischknecht, R., Hendriks, A.J., Van de Meent, D., Ragas, A.D.M.J, Reijnders, L., Struijs, J. 2006. Is cumulative fossil energy demand a useful indicator for the environmental performances of products? Environmental Science \& Technology 40,641-648.

Huijbregts, M.A.J., Hellweg ,S., Frischknecht, R., Hendriks, W.M., Hungerbuhler, K., Hendriks, A.J. 2010. Cumulative energy demand as predictor for the environmental burden of commodity production. Environmental Science \& Technology 44,2189-2196.

Micale, C. 2015. Bio-methane generation from biogas upgrading by semipermeable membranes: An experimental, numerical and economic analysis. Ener Proc 82,971-977.

Renou, S., Givaudan, J.G., Paoulain, S., Dirassouyan, F., Moulin, P. 2008. Landfill Leachate treatment. Rev. Opport. J. Hazard. Mater. $150,468-493$.

Rigamonti, L., Grosso, M. Giugliano, M. 2009, Life cycle assessment for optimising the level of separated collection in integrated MSW management system. Waste Management 29,934-944.

Wernet, G., Bauer, C., Steubing, B., Reinhard, J., Moreno-Ruiz, E., Weidema, B. 2016. The ecoinvent database version 3 (part I): overview and methodology. In J Life Cycle Assess 21,1218-1230.

WFD (Waste Framework Directive). 2008, Directive 2008/98/EC of the European Parliament and of the Council of 19 November 2008 on waste and repealing certain Directives. Official Journal of the European Union 22.11.2008 N. L312/3. 